\title{
Bacterioplankton, Picoeukaryotes and Synechococcus Distribution Associated with Seagrass in South Coast of Hainan Island, China
}

\author{
Dingtian Yang1*, Xiujuan Shan'², Sumin Liu ${ }^{1}$ \\ ${ }^{1}$ State Key Laboratory of Oceanography in the Tropics, South China Sea Institute of Oceanology, Chinese \\ Academy of Sciences, Guangzhou, China \\ ${ }^{2}$ Shandong Provincial Key Laboratory of Fishery Resources and Ecological Environment, Yellow Sea Fisheries \\ Research Institute, Chinese Academy of Fishery Sciences, Qingdao, China \\ Email: ${ }^{*}$ dtyang@scsio.ac.cn
}

Received 15 May 2014; revised 18 June 2014; accepted 14 July 2014

Copyright $@ 2014$ by authors and Scientific Research Publishing Inc.

This work is licensed under the Creative Commons Attribution International License (CC BY). http://creativecommons.org/licenses/by/4.0/

(c) (;) Dpen Access

\section{Abstract}

Seagrass ecosystem is a potential bank for carbon sink. In the paper, we compared the distribution of bacterioplankton, picoeukaryotes and Synechococcus in seagrass ecosystem in Xincun Bay and coral ecosystem in Sanya Bay and found that quantity of bacterioplankton was higher in seagrass ecosystem, and picoeukaryotes had similar distribution pattern with that of bacterioplankton. However, quantity of Synechococcus distribution was higher in coral ecosystem and higher in Sanya Bay. Comparing the unit of quantity of bacterioplankton, picoeukaryotes and Synechococcus in Xincun Bay with that of Sanya Bay, open sea of the South China Sea and Indian Ocean, results showed that the highest quantity of bacterioplankton was in Xincun Bay, and the lowest was in open sea of the South China Sea. The quantity of picoeukaryotes had the similar pattern with that of bacterioplankton. Pattern of Synechococcus quantity was different, which was the highest in Sanya Bay. These results indicated that seagrass ecosystem was more suitable for bacterioplankton and picoeukaryotes growth.

\section{Keywords}

Seagrass, Bacterioplankton, Picoeukaryotes, Synechococcus

${ }^{*}$ Corresponding author.

How to cite this paper: Yang, D.T., Shan, X.J. and Liu, S.M. (2014) Bacterioplankton, Picoeukaryotes and Synechococcus Distribution Associated with Seagrass in South Coast of Hainan Island, China. Natural Resources, 5, 454-461. 


\section{Introduction}

Knowledge of the distribution of multiple species in time and space within a shared habitat is valuable for understanding how an ecosystem functions [1] and judging whether it is carbon sources or sinks. Seagrass ecosystem is very important component of coastal carbon cycle, and also very important for keeping coastal carbon balance and buffering regional ocean acidity. Globally, seagrass ecosystems could store as much as 19.9 Pg organic carbon [2]; however present rates of seagrass loss could result in the release of up to 299 Tg carbon per year [2]. Studying pico-species distribution in seagrass ecosystem can provide firsthand data for calculating ocean carbon flux and providing trail clues thread for searching unkown carbon sinks.

Except for seagrass itself, carbon in seagrass ecosystem also include phytoplankton, bacteria, fish and benthos, etc. On the leaves of seagrass, there are many kinds of periphyton growing on it. Some researches reported that about 150 species of microalgae on seagrass [3] and primary production of these algae occupied about 20\% - 60\% of total seagrass primary production [4]. Moncreiff [5] studied seagrass primary production in Mississippi Sound and found that primary production of periphyton, benthic diatom, phytoplankton occupied by $87 \%$ of the whole seagrass bed. Some researches regarded that benthic algae occupied $33 \%-42 \%$ of the seagrass ecological primary production [6].

Planktons (bacterioplankton, picoeukaryotes, Synechococcus) can be affected by seagrass for the particular environment, such as hydrodynamics and concentrations of dissolved organic matters and nutrients. Seagrass can affect bacterioplankton distribution to a great extent. Some researchers reported that the presence of seagrass significantly affected the overlying water column, especially microbial activity were also significantly higher over areas of dying seagrass than over healthy or dead areas [7]. Some researchers reported that number of bacteria in seagrass bed was about ten times more than that without [8]. In the process of seagrass growing, seagrass secrets DOC into water and which can be utilized by algae and bacteria, which facilitate dissolved carbon transferred to particle carbon [9]. Diurnal variation of bacterioplankton was also great, cell production rates increased by 5 - to 10-fold during the morning and decreased during the afternoon [10].

Among Cyanobacteria, the genus Synechococcus dominates the prokaryotic component of the picophytoplankton in the oceans, contributing to a significant portion of total marine primary production. Some reported that Synechococcus can contribute an important fraction (>50\%) of the biomass and total production of phytoplankton [11]. Some researchers studied the effects of seagrass on Synechococcus-like cells and found that Synechococcus-like cells (SYN) decreased after 3 days when contacted with seagrass ecosystem, most likely due to grazing control [12].

However, little attention had been paid on pico-particles in seagrass ecosystem in Xincun Bay, Hainan, China. The paper mainly study bacterioplankton, picoeukaryotes and Synechococcus associated with seagrass with in situ observations. Based on measurement of quantity of bacterioplankton, picoeukaryotes and Synechococcus, unit of number of pico-particles were compared in coastal and ocean open waters and we tried to find to what extent pico-particles (bacterioplankton, picoeukaryotes and Synechococcus) associated with seagrass is.

\section{Material and Methods}

\subsection{Sites Description}

Xincun Bay, where seagrass grows luxuriantly, was chosen as main study sites. In order to compare unit quantity of pico-plankton (bacterioplankton, picoeukaryotes and Synechococcus), Sanya Bay, Daya Bay, open sea of South China Sea and Indian Ocean was selected as comparison sites.

Samples of bacterioplankton, picoeukaryotes and Synechococcus in Xincun Bay and Sanya Bay were gathered from September 24 to October 1, 2012. Xincun Bay (Figure 1), an almost closed bay with only one narrow tunnel connected with the open sea to the southwest, with an area of more than $13.1 \mathrm{Km}^{2}$ and an aqua-cultural area of more than 52,500 $\mathrm{m}^{2}$ [13]. Four species of seagrass (Enhalus acoroides, Thalassia hemperichii, Cymodocea rotundata and Halodule uninervis) were found distributed in Xinchun Bay, with Enhalus acoroides and Thalassia hemperichii being the dominant species [14].

Sanya Bay, located in the south of Hainan Province, to the west of Xincun Bay, with location of $109^{\circ} 20^{\prime} \mathrm{E}$ $109^{\circ} 30^{\prime} \mathrm{E}, 18^{\circ} 11^{\prime} \mathrm{N}-18^{\circ} 18^{\prime} \mathrm{N}$ and an area of $120 \mathrm{Km}^{2}$. According to the results of Yang's study [14], seagrass distributed with high density along the coast of Sanya Bay in 1970s. However, seagrass is distributed sparsely at present due to the frequent anthropogenic activities (Yang, 2008) and now the area of seagrass distribution 


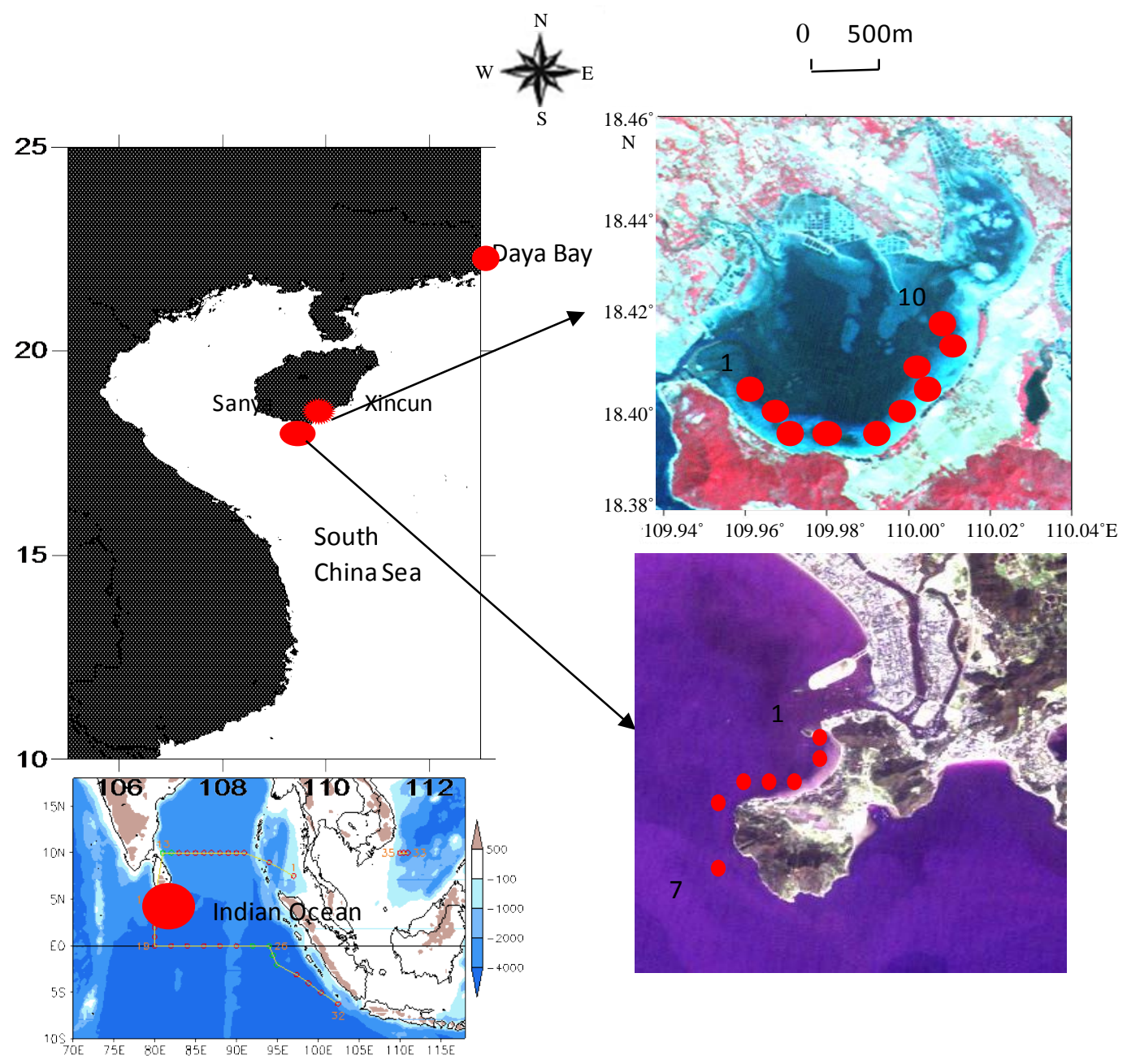

Figure 1. Sampling sites in Xincun and Sanya Bay, Hainan Province, China.

is very small.

Latitude and longitude of sampling sites in Sanya Bay were showed as following: SY1 (109.4761, 18.21306); SY2 (109.4733, 18.2125); SY3 (109.4719, 18.21167); SY4 (109.4711, 18.20528); SY5 (109.4833, 18.21639); SY6 (109.4844, 18.21722); SY7 (109.4872, 18.22056); Sampling sites were in in Xincun Bay were as following: XC1 (109.9747, 18.41); XC2 (109.9744, 18.40944); XC3 (109.9431, 18.40778); XC4 (109.9775, 18.40833); XC5 (109.9803, 18.40611); XC6 (109.985, 18.40222); XC7 (109.9881, 18.40167); XC8 (109.995, 18.40139); XC9 (109.9994, 18.40028); XC10 (110.0111, 18.41083).

Samples of bacterioplankton, picoeukaryotes and Synechococcus in Daya Bay and open sea of South China Sea were gathered in 2012, and in Indian Ocean were from 12 April to 4 May 2011. These samples were only used as comparison with unit of quantity of pico-plankton in seagrass ecosystem.

\subsection{In Situ Sampling}

Samplings were conducted in coastal waters in Xincun Bay and Sanya Bay, in September, 2012 and offshore water in South China Sea and Indian Ocean in May, 2012. Sample sites were chosen as seagrass and coral and none of these substrates. Water samples were taken using bottles at $0.5 \mathrm{~m}$ depths near the surface. Onboard the ship, water samples were processed immediately after collection. Certain volume of water (30 mL) was filtered onto the nylon filter, about $3 \mathrm{~mL}$ of filtered water was input in small plastic tube and formaldehyde was added in the sample, finally the samples were preserved in liquid nitrogen and were brought back for laboratory analyzing. 


\subsection{Laboratory Analyzing}

In laboratory, the autofluorescent properties of photosynthetic plankton can be exploited by flow cytometry in order to characterize abundance and community structure, bacterium, Synechococcus and picoeukaryotes were detected. EXCEL software was used for calculating number and carbon of these constituents.

\section{Results}

\subsection{Comparison of Bacterioplankton, Picoeukaryotes and Synechococcus in Seagrass Dominant and Not Dominant Ecosystem}

\subsubsection{Bacterioplankton Distribution in Seagrass Dominant and Not Dominant Ecosystem}

Bacteria are the very important components in seagrass ecosystem. Epiphytic bacteria, benthic bacteria and bacterioplankton are all very important for carbon cycle of seagrass and coral ecosystem. In the paper, bacterioplankton in seagrass ecosystem in Xincun Bay and coral system in Sanya Bay was studied, Figure 2 showed that unit of number of bacterioplankton in seagrass ecosystem in Xincun bay ranged from $1.82 \times 10^{6}$ (at sample site 5) to $1.82 \times 10^{7}$ (at sample site 9), and $5.90 \times 10^{6}$ on average; however, in coral ecosystem in Sanya Bay, quantity of bacteria only ranged from $2.49 \times 10^{5}$ to $1.39 \times 10^{6}$, and $5.85 \times 10^{5}$ on average. Unit of quantity of bacterioplankton was about one order of magnitude differences between seagrass and coral ecosystem and Unit of quantity of bacterioplankton in seagrass ecosystem was relatively greater.

\subsubsection{Synechococcus Distribution in Seagrass Dominant and Not Dominant Ecosystem}

Synechococcus is the main component of picophytoplankton in the ocean. Figure 3 showed that unit of number of Synechococcus in seagrass ecosystem in Xincun bay ranged from $3.52 \times 10^{3}$ to $2.34 \times 10^{4}$, and $8.77 \times 10^{3}$ on average; however, in coral ecosystem in Sanya Bay, quantity of Synechococcus ranged from $2.46 \times 10^{4}$ to 5.77 $\times 10^{4}$, and $4.19 \times 10^{4}$ on average. Unit of quantity of Synechococcus was also about one order of magnitude differences between seagrass and coral ecosystem. By comparison of Synechococcus in Sanya Bay and Xincun

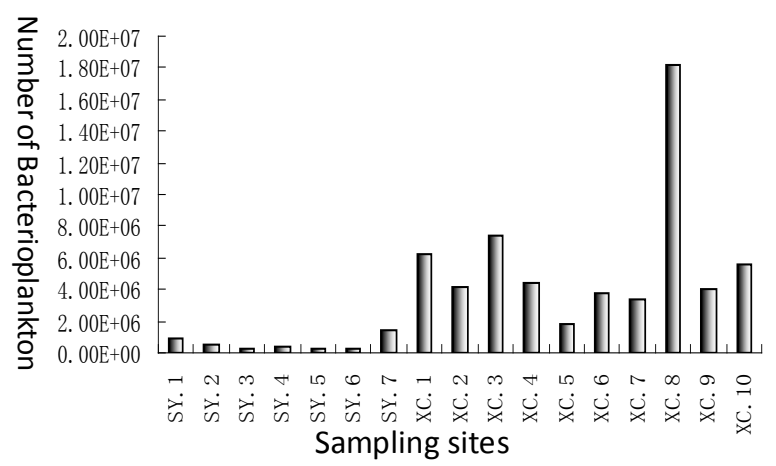

Figure 2. Bacterioplankton in Xincun Bay and Sanya Bay.

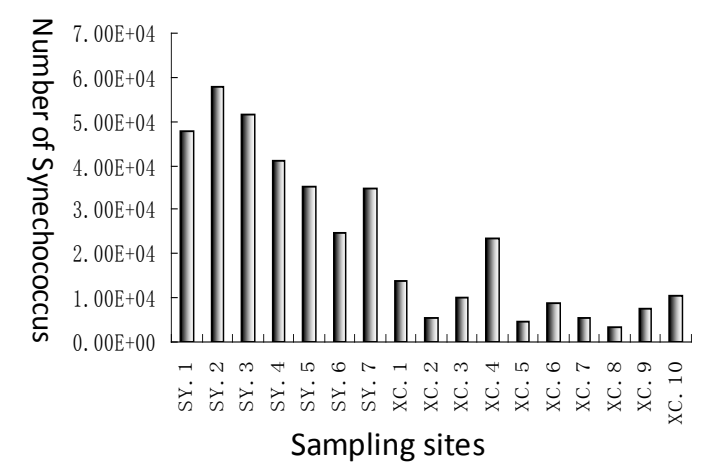

Figure 3. Synechococcus in Xincun Bay and Sanya Bay. 
Bay, and found that the trend was in the opposite way with that of bacterioplankton.

\subsubsection{Picoeukaryotes Distribution in Seagrass Dominant and Not Dominant Ecosystem} Microbial, single-celled eukaryotes play a wide range of ecological roles in marine environments.

Figure 4 showed that picoeukaryotes in coral and seagrass ecosystem. Unit of number of picoeukaryotes in seagrass ecosystem in Xincun bay ranged from $5.08 \times 10^{2}$ to $5.6 \times 10^{3}$, and $2.35 \times 10^{3}$ on average; however, in coral ecosystem in Sanya Bay, quantity of bacteria ranged from $4.08 \times 10^{2}$ to $1.24 \times 10^{3}$, and $5.57 \times 10^{2}$ on average. Unit of quantity of picoeukaryotes was about one order of magnitude differences between seagrass and coral ecosystem. By comparison of picoeukaryotes in Sanya Bay and Xincun Bay, and found that the trend was in the similar way with that of bacterioplankton.

\subsection{Relationship between Bacterioplankton and Picoeukaryotes, Synechococcus}

Number of bacterioplankton and picoeukaryotes and Synechococcus in Sanya Bay and Xincun Bay was measured and the relationship between them was obtained.

Figure 5 showed the relationship between Synechococcus and bacterioplankton with increasing number of Synechococcus, the number of bacterioplankton decreased, and relationship between them was in the relationship of negative exponential.

Relationship between picoeukaryotes and bacterioplankton were also studied. However, the relationship between picoeukaryotes and bacterioplankton was different with that of Synechococcus and bacterioplankton. As Figure 6 indicates, with increasing number of picoeukaryotes, the number of bacterioplankton increased correspondently, and relationship between them was in the relationship of positively linear.

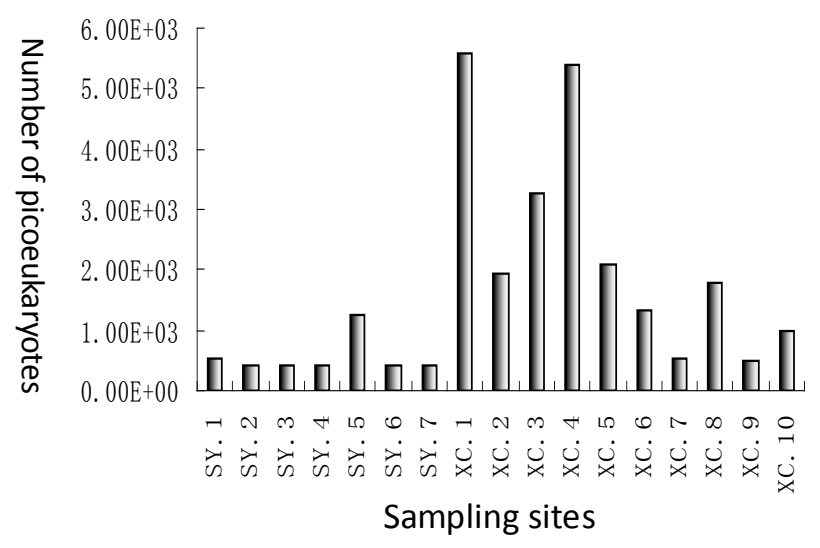

Figure 4. Picoeukaryotes in Xincun Bay and Sanya Bay.

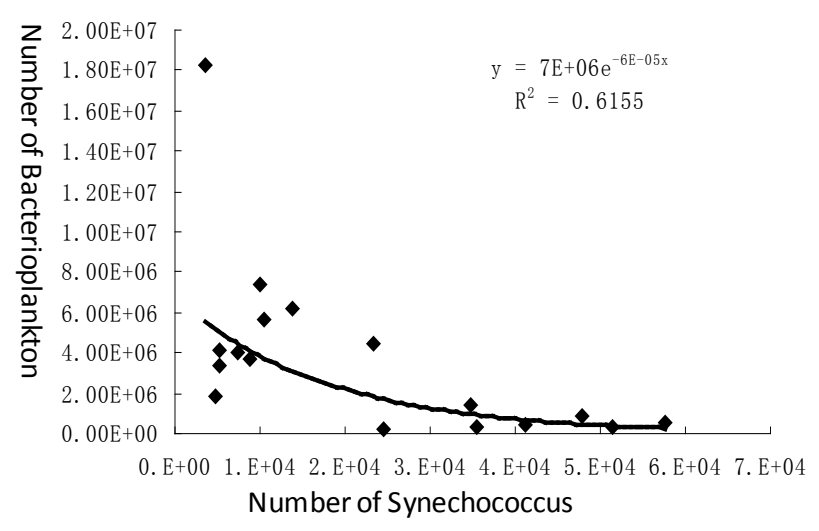

Figure 5. Relationship between bacterioplankton and Synechococcus. 


\section{Discussions}

In the paper, study sites were all chosen at tropical area where temperature variation was not great. Among the three groups, bacterioplanktons are heterotrophic, bacterial activity in seagrass meadows is dependent on seagrass growth and availability of organic nutrients. The difference in these areas may be related to different organic matter composition and availability.

Synechococcus are autotrophic, which compete with seagrass for inorganic nutrients and light. Compared with other ecosystem, unit of number of Synechococcus in seagrass was relatively lower. Still, some researchers reported that a total of 19 different cyanobacteria taxa were encountered in seagrass [15].

Regional bacterioplankton distributions in Xincun Bay, Sanya Bay, open water of South China Sea and Indian Ocean were compared in the paper (Figure 7). Unit of quantity of bacterioplankton was the highest in Xincun Bay, the lowest in open water of South China Sea. The sequence of unit of quantity of bacterioplankton from the highest to the lowest is Xincun Bay > Sanya Bay > Indian Ocean > South China Sea. Unit of quantity of bacterioplankton on average was from $5.90 \times 10^{6}$ to $1.52 \times 10^{4}$.

Synechococcus distributions in Xincun Bay, Sanya Bay, Daya Bay and open water of South China Sea and Indian Ocean were compared in the paper (Figure 8). Unit of quantity of Synechococcus was different with that of bacterioplankton. The highest was in Xincun Bay, the lowest was in Indian Ocean. The sequence from the highest to the lowest is Sanya Bay $>$ Daya Bay $>$ Xincun Bay $>$ South China Sea $>$ Indian Ocean. Unit of quantity of Synechococcus on average was from $2.93 \times 10^{4}$ to $2.47 \times 10^{3}$.

Picoeukaryotes distributions in Xincun Bay, Sanya Bay, Daya Bay and open water of South China Sea and Indian Ocean were compared in the paper (Figure 9). Unit of quantity of Picoeukaryotes was similar with that

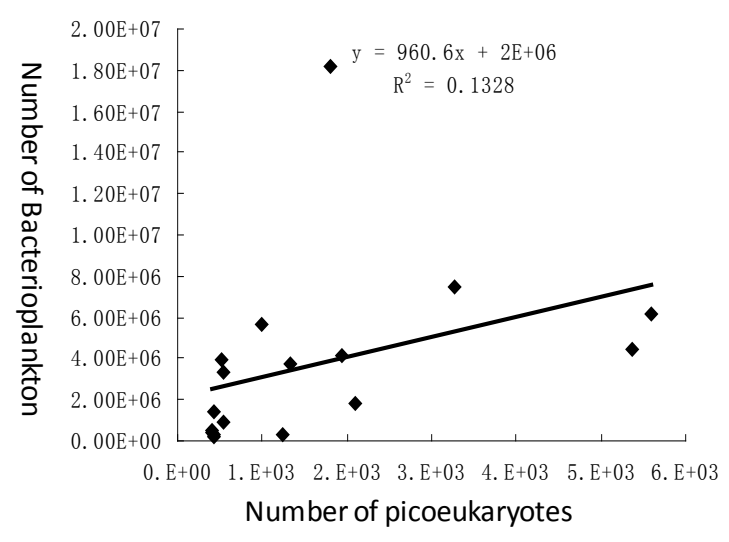

Figure 6. Relationship between bacterioplankton and picoeukaryotes.

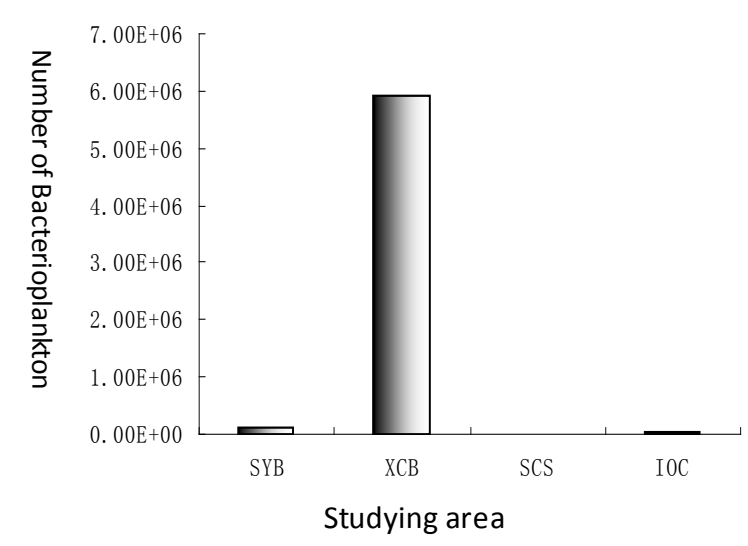

Figure 7. Comparison of numbers of bacterioplankton on average in Xincun Bay, Sanya Bay, open water of South China Sea and Indian Ocean. 
of bacterioplankton. The highest was in Xincun Bay, the lowest was in open water of South China Sea. The sequence from the highest to the lowest is Xincun Bay $>$ Daya Bay $>$ Sanya Bay $>$ Indian Ocean $>$ South China Sea. Unit of quantity of picoeukaryotes was from $2.35 \times 10^{3}$ to $2.75 \times 10^{2}$ on average.

By comparison of bacterioplankton, picoeukaryotes and Synechococcus between coastal and open ocean water and found that coastal water had high concentrations of the three pico-particles. The unit of quantity of these pico-particles was more than one order magnitude between coastal and open ocean water on average. These results indicated that unit of primary production of coastal water was about ten times than that of open ocean water.

High primary production in seagrass produced high concentration of dissolved organic carbon, which provided nutrients for bacterioplankton growth in seagrass ecosystem. Perhaps these were the main reason of high concentration of bacterioplankton in seagrass ecosystem.

\section{Conclusions}

Bacterioplankton, picoeukaryotes and Synechococcus in Xincun Bay, Sanya Bay, Daya Bay and open water of South China Sea and Indian Ocean were studied and results showed:

1) Bacterioplankton in seagrass bed range from $1.82 \times 10^{6}$ (at sample site 5) to $1.82 \times 10^{7}$ (at sample site 9), and $5.90 \times 10^{6}$ on average; Unit of quantity of bacterioplankton was more than one order of magnitude differences than other ecosystems.

2) Unit of quantity of Synechococcus is the highest in coral system in Sanya Bay, which was different with that of bacterioplankton.

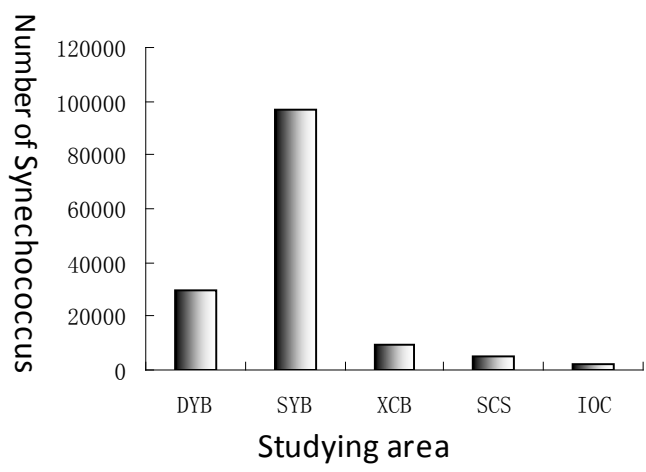

Figure 8. Comparison of numbers of Synechococcus on average in Xincun Bay, Sanya Bay, Daya Bay, open water of South China Sea and Indian Ocean.

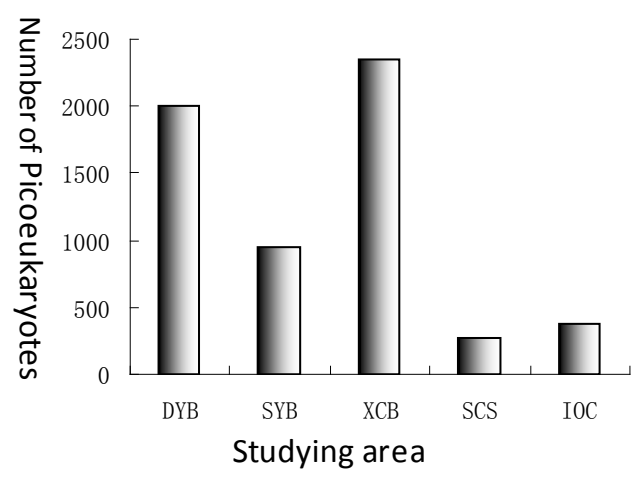

Figure 9. Comparison of numbers of bacterioplankton on average in Xincun Bay, Sanya Bay, Daya Bay, open water of South China Sea and Indian Ocean. 
3) Unit of quantity of bacterioplankton had negative exponential relationship with that of Synechococcus.

4) The sequence of unit of quantity of bacterioplankton from the highest to the lowest is Xincun Bay $>$ Sanya Bay $>$ Indian Ocean $>$ South China Sea. Synechococcus is Sanya Bay $>$ Daya Bay $>$ Xincun Bay $>$ South China Sea $>$ Indian Ocean. Picoeukaryotes is Xincun Bay $>$ Daya Bay $>$ Sanya Bay $>$ Indian Ocean $>$ South China Sea.

5) These results indicated that the environment of seagrass was more suitable for bacterioplankton and picoeukaryotes growth.

\section{Acknowledgements}

The National Basic Research Program of China (973 Program) under grant No. 2010CB951203 and 2013 CB956503; the National Natural Sciences Foundation of China under grant No. 41176161; State Key Laboratory of Lake Science and Environment (2012SKL004); Foundation of Guangdong Province and Chinese Academy of Sciences cooperation under grant No. 2011B090300059; Foundation of Science and technology of Guangdong Province under grant No. 2012A031100008.

\section{References}

[1] Konopka, A. (2009) What Is Microbial Community Ecology? The ISME Journal, 3, 1223-1230. http://dx.doi.org/10.1038/ismej.2009.88

[2] Fourqurean, J.W., Duarte, C.M., Kennedy, H., Marbà, N., Holmer, M., Mateo, M.A., Apostolaki, E.T., Kendrick, G.A., Krause-Jensen, D., McGlathery, K.J., and Serrano, O. (2012) Seagrass Ecosystems as a Globally Significant Carbon Stock. Nature Geoscience, 5, 505-509. http://dx.doi.org/10.1038/ngeo1477

[3] Phillips, R.C. and Mcroy, C.P. (1980) Handbook of Seagrass Biology. Garland STPM Press, New York, 353.

[4] Borowitzka M.A. And Lethbridge, R.C. (1989) Seagrass Epiphytes. In: Larkum, A.W.D., McComb, A.J. and Shepherd, S.A., Eds., Biology of Seagrasses, Elsevier, Amsterdam, 458-499.

[5] Moncreiff, C.A., Sullivan, M.J. and Daehnick, A.E. (1992) Primary Production Dynamics in Seagrass Beds of Mississippi Sound: The Contributions of Seagrass, Epiphytic Algae, Sand Microflora and Phytoplankton. Marine Ecology Progress Series, 87, 161-171. http://dx.doi.org/10.3354/meps087161

[6] Kaldy, J.E., Eldridge, P.M., Onuf, C.P., et al. (2002) Carbon Budget for a Sub-Tropical Seagrass Dominated Coastal Lagoon: How Important Are Seagrasses to Total Ecosystem Net Primary Production? Estuaries, 25, 528-539. http://dx.doi.org/10.1007/BF02804888

[7] Jones, R.D., Bugden, J.B.C. and Guerrero, M.A.J. (1998) Spatial and Temporal Variation of Marine Bacterioplankton in Florida Bay, USA. Journal of Coastal Research, 14, 1304.

[8] Delille, D., Canon, C. and Windeshausen, F. (1996) Comparison of Planktonic and Benthic Bacterial Communities Associated with a Mediterranean Posidonia Seagrass System. Botanica Marina, 39, 234-249. http://dx.doi.org/10.1515/botm.1996.39.1-6.239

[9] Jones, W.B., Cifuentes, L.A. and Kaldy, J.E. (2003) Stable Carbon Isotope Evidence for Coupling between Sedimentary Bacteria and Seagrasses in a Sub-Tropical Lagoon. Marine Ecology Progress Series, 255, 15-25. http://dx.doi.org/10.3354/meps255015

[10] Moriarty, D.J.W. and Pollard, P.C. (1982) Diel Variation of Bacterial Productivity in Seagrass (Zostera capricorni) Beds Measured by Rate of Thymidine Incorporation into DNA. Marine Biology, 72, 165-173. http://dx.doi.org/10.1007/BF00396917

[11] Llabrés, M.M. and Agustí, S. (2006) Picophytoplankton Cell Death Induced by UV Radiation: Evidence for Oceanic Atlantic Communities. Limnology and Oceanography, 51, 21-29. http://dx.doi.org/10.4319/lo.2006.51.1.0021

[12] Wit, R., Troussellier, M., Courties, C., Buffan-Dubau, E. and Lemaire, E. (2012) Short-Term Interactions between Phytoplankton and Intertidal Seagrass Vegetation in a Coastal Lagoon (Bassin d'Arcachon, SW France), Hydrobiologia, 699, 55-68.

[13] Yang, D.T. and Yang, C.Y. (2009) Detection of Seagrass Distribution Changes from 1991 to 2006 in Xincun Bay, Hainan, with Satellite Remote Sensing. Sensors, 9, 830-844. http://dx.doi.org/10.3390/s90200830

[14] Yang, Z.D. (1979) The Geographical Distribution of Seagrass. Bulletin of Limnology and Oceanography, 2, 41-46. (in Chinese)

[15] Hamisi, M.I., Lyimo, T.J. and Muruke, M.H.S. (2004) Cyanobacterial Occurrence and Diversity in Seagrass Meadows in Coastal Tanzania. Western Indian Ocean Journal of Marine Science, 3, 113-122. 
Scientific Research Publishing (SCIRP) is one of the largest Open Access journal publishers. It is currently publishing more than 200 open access, online, peer-reviewed journals covering a wide range of academic disciplines. SCIRP serves the worldwide academic communities and contributes to the progress and application of science with its publication.

Other selected journals from SCIRP are listed as below. Submit your manuscript to us via either submit@scirp.org or Online Submission Portal.
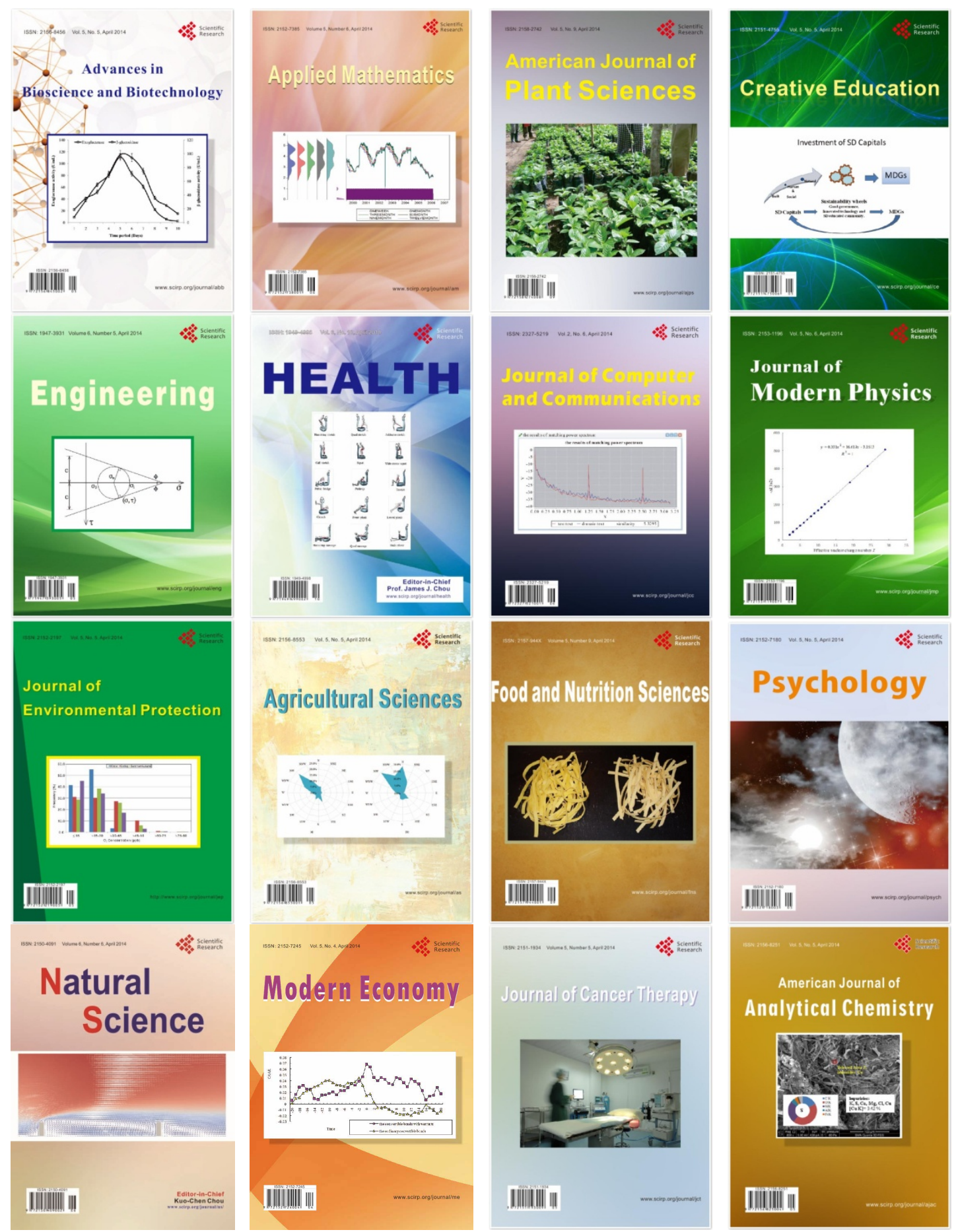